\title{
Peran Pimpinan Pondok Pesantren Dalam Pengembangan Dakwah
}

\author{
Afifatu Fachrudin ${ }^{1 *}$, Herman $^{2}$, Saeful Anwar ${ }^{3}$ \\ ${ }^{12}$ Jurusan Manajemen Dakwah, Fakultas Dakwah dan Komunikasi, UIN Sunan Gunung Djati, \\ Bandung \\ ${ }_{3}^{3}$ urusan Pengembangan Masyarakat Islam, Fakultas Dakwah dan Komunikasi, UIN Sunan \\ Gunung Djati, Bandung \\ *Email afifatufachrudin@gmail.com
}

\begin{abstract}
ABSTRAK
Tujuan penelitian ini adalah untuk mengetahui bagaimana peran pimpinan pondok pesantren YPI An-Nur Garut dalam penentuan metode dan program pengembangan dakwah dan bentuk pelaksanaan serta evaluasi dalam kegiatan pengembangan dakwah. Metode deskriptif digunakan dalam penelitian ini karena metode ini dipandang relevan untuk menggali dan menganalisis fenomena yang terjadi secara empiris. Teknik penelitian yang digunakan adalah observasi, wawancara, dokumentasi, dan analisis data kualitatif. Berdasarkan pengamatan dan analisis data penelitian, diperoleh kesimpulan bahwa peran KH. Ahmad Badruddin dalam pengembangan dakwah, dipandang sebagai seorang tokoh, pemimpin teladan, juga penghubung. Dalam penentuan metode dalam peningkatan kualitas para da'i, menggunakan tiga. Kemudian program yang dikembangkan, meliputi pengembangan pondok pesantren, madrasah, ekstrakulikuler, serta pembinaan dan pengembangan organisasi. Bentuk pelaksanaan dan evaluasi kegiatan tarbiyatul mubalighin memiliki beberapa mekanisme sendiri, diantaranya dari tahap perencanaan sampai dengan evaluasi.
\end{abstract}

Kata Kunci : Peran; Pimpinan; Pondok Pesantren; Pengembangan Dakwah 


\section{ABSTRACT}

The purpose of this study was to determine the role of the leadership of the YPI An-Nur Garut Islamic boarding school in determining methods and programs for the development of da'wah and the form of implementation and evaluation in the development of da'wah activities. Descriptive method is used in this research because this method is considered relevant for exploring and analyzing phenomena that occur empirically. The research technique used was observation, interviews, documentation, and qualitative data analysis. Based on observations and analysis of research data, it is concluded that the role of KH. Abmad Badruddin in the development of da'wah, is seen as a figure, a role model, as well as a liaison. In determining the method of improving the quality of the da'i, using three. Then the program developed includes the development of Islamic boarding schools, madrasas, extracurricular activities, as well as coaching and organizational development. The form of implementation and evaluation of tarbiyatul mubalighin activities has several mechanisms of its own, including from planning to evaluation.

Keywords : Role; Leader; Islamic Boarding School; Da'wah Development

\section{PENDAHULUAN}

Perkembangan lembaga pesantren selalu melahirkan unsur-unsur baru tanpa harus meninggalkan ataupun menghilangkan unsur yang sudah terbentuk. Terjadinya perubahan dan pengembangan atas unsur tersebut membuat pondok pesantren tersebut tetap eksis dan senantiasa berfungsi bagi pendidikan dan perubahan sosial (Sukamto, 1999:4). Nampaknya pesantren hari ini perlu dibaca sebagai warisan sekaligus kebudayaan intelektual nusantara, sebab bisa memberikan kontribusi terhadap lahirnya khasanah intelektual-intelektual muslim. Walapun kiprah pesantren hanya di tararan sosial religius namun upaya membangun intelektual muslim yang mampu mandiri dengan sifat kebersamaanya sudah mengakibatkan Indonesia sebagai negara yang ditakuti oleh para kolonial serta mengalami kejayaan pada masanya, serta hingga ketika ini juga pondok pesantren ikut andil pada menciptakan rakyat yang berbudaya yang menunjuk kepada religiusnya (Wahid, 1999:1).

Sebagai lembaga pendidikan, pesantren ikut bertanggung jawab dalam pencerdaskan bangsa dan merawat tradisi keagamaan (Islam) di Indonesia. Lebih dari itu, para santri setelah terjun ke masyarakat dan menyebar ke segala bidang kehidupan, maka dari itu kelengkapan pengetahuan sangatlah penting guna memberi bekal kepada para santri. Beberapa tantangan besar dakwah Islam hari 
ini adalah masih banyaknya kebodohan dan pengangguran di masyarakat, dua hal tersebut harus dicarikan solusinya bersama baik oleh pemerintahan, Organisasiorganisasi Islam, da'i dan ulama, lembaga-lembaga pendidikan Islam, dan seluruh elemen umat Islam lainnya. Pondok pesantren YPI An-Nur Garut sebagai salah satu lembaga pendidikan Islam melalui berbagai jenjang pendidikan serta kurikulum pengajaran berupaya untuk mendidik para santri agar mampu mengatasi permasalah dakwah. Kemudian, Pondok pesantren YPI An-Nur Garut sebagai pesantren dengan model pendidikan Salafi, Para santri dibimbing dan tinggal di asrama serta terkontrol selama 24 jam, Para santri dididik untuk memahami, dan mengamalkan ilmu yang diajarkan di pondok pesantren. Secara historis, pondok pesantren YPI An-Nur Garut melakukan perngembangan dakwah dalam banyak aspek baik seperti misalnya kajian, program, dan sarana prasarana pendukung dan tentunya hal ini tidak lepas dari hasil peran seorang pimpinan dakwah di pesantren dalam memciptakan inovasi-inovasi sehingga menjadi lebih maju dan berkembang.

Dari latar belakang tersebut kemudian dirumuskan beberapa rumusan masalah yaitu : Bagaimana bentuk peran pimpinan pondok pesantren YPI AnNur Garut dalam penentuan metode dan program pengembangan Dakwah ? Bagaimana bentuk pelaksanaan dan evaluasi kegiatan dalam pengembangan dakwah Pondok pesantren YPI An-Nur Garut? Kemudian tujuan penelitian ini adalah untuk mengetahui bentuk peran pimpinan pondok pesantren YPI An-Nur Garut dalam penentuan metode dan program pengembangan dakwah dan untuk mengetahui bentuk pelaksanaan dan evaluasi kegiatan dalam pengembangan pondok pesantren YPI An-Nur Garut.

Untuk menghindari kesamaan penulisan, maka penulis sematkan beberapa hasil penelitian sebelumnya yang memiliki relevansi dengan penelitian ini, diantaranya adalah : 1) Penelitian yang ditulis oleh Jaka Billal Gumbira Jurusan Manajemen Dakwah Universitas Islam Negeri Sunan Gunung Djati Bandung yang dilakukan pada tahun 2014. Adapun judul saudara Jaka yaitu, Implementasi Manajemen Dakwah dalam Pengelolaan Pesantren Salafiyah Al-Ittihadiyah Garut. Dalam penelitannya menerangkan bahwa pesantren tersebut menggunakan pola manajemen dakwah, dengan menggunakan fungsi-fungsi manajemen satu persatu seara bertahap. Kemudian adanya pembagian kerja, penggerakan dan pengawasan dalam pelaksanaan progam pesantren. Selain itu pesantren juga melakukan pengembangan terhaap manajemen dakwah itu sendiri; 2) Penelitian yang ditulis 
A.Fachrudin, Herman, S. Anwar.

oleh M. Gozali jurusan Manajemen Dakwah UIN Sunan Gunung Djati Bandung. Adapun judul nya ialah Strategi Pondok Pesantren dalam Pengembangan Dakwah. Dalam penelitian ini, memfokuskan tentang majelis ta'lim as-sanusiayah dalam menerapkan pola manajemen sudah cukup berhasil melalui perencanaan yang diterapkan. Dalam merealisasikan perencanaan program kegiatan majelis yang ditetapkan; 3) Penelitian yang ditulis oleh Vella Andriani Murlihah, jurusan Manajemen Dakwah UIN Sunan Gunung Djati Bandung. Adapun judulnya ialah Manajemen Strategi Pondok Pesantren Dalam Meningkatkan Kinerja Pengurus. Dalam penelitian ini menemukan bahwa strategi Pondok Pesantren Al-Falah adalah mendukung kebijakan pertumbuhan yang agresif yang diformulasikan dalam stategi utama berupa pertumbuhan terkonsentrasi, berdasarkan analisis lingkungan internal dan eksternalnya juga implementasi yang terkoordinir. Serta tingkat evaluasi strategis yang intensif sehingga inovasi dan pengendalian strategi selalu sesuai dengan tuntutan dan perubahan zaman. Dapat disimpulkan bahwa manajemen strategi pada pondok pesatren Al-Falah telah dijalankan dengan baik dan menunjukan keberhasilan yang signifikan dalam upaya meningkatkan kinerja pengurus.

Metode yang digunakan dalam penelitian ini adalah Deskriptif Kualitatif, tujuannya untuk mempelajari secara intensif dan memberikan gambaran untuk mendeskripsikan secara sistematik, akurat, dan fakta mengenai Peran Pimpinan Pondok Pesantren Dalam Pengembangan Dakwah. Jenis data yang digunakan dalam penelitian ini adalah kualitatif. Kualitatif adalah penelitian yang berlandaskan pada positivism yang digunakan untuk meneliti pada kondisi objek yang alamiah (sebagai lawan eksperimen) dimana peneliti sebagai instrument kunci, pengambil sample sumber data dilakukan secara purepositive dan snowball, teknik pengumpulan data dengan triangulasi (gabungan), analisis data yang bersifat induktif/ kualitatif dan hasil penelitian lebih menekankan makna daripada generalisasi (Sadiah, 2015:19).

\section{LANDASAN TEORITIS}

Teori yang dijadikan landasan dalam penelitian ini adalah teori Peran, Pimpinan, Pondok Pesantren, dan pengembangan dakwah. Peran adalah aspek dinamis pada suatu kedudukan seseorang ketika memenuhi hak dan kewajiban sesuai dengan kedudukannya. Ada perbedaan antara peran dengan posisi, karena peran itu sebagai suatu proses yang menunjuk pada fungsi dan penyesuaian diri. Sedangkan 
posisi ialah individu sebagai aspek statis pada masyarakat sosial (Soekanto, 2010:212).

Menurut penjelasan Mintzberg, peran diartikan sebagai pola prilaku yang diharapkan seseorang dalam satu unit fungsional. Kemudian ia membagi peran ke dalam tiga peran utama seorang pemimpin, yaitu : (a) Peran interpersonal, Peran ini berhubungan dengan proses operasional organisasi, yang melibatkan orang lain atau bawahan. Pemimpin berperan sebagai seorang tokoh, pemimpin, penghubung; (b) Peran informasional, dalam peran ini pimpinan menjadi seorang pembicara pada kondisi tertentu. Dalam melaksanakan peran ini, pemimpin berperan sebagai pemonitor informasi, pembagi informasi; dan sebagai juru bicara; (c) Peran desisional, peran ini berhubungan dengan tugas pokok dan batasan anggota dalam organisasi. Pemimpin berperan sebagai wirausaha sebagai inovator dalam pengembangan dan peningkatan kualitas organisasi; kemudian sebagai peredam gangguan, yang merespon terhadap tekanan atau gangguan, seperti pelanggaran; sebagai pengalokasi sumber, yang menentukan dan mengatur alokasi sumber daya pada posisi yang tepat; dan terakhir sebagai perunding menjadi penengah ketika ada sebuah konflik internal pada semua level organisasi, serta melakukan negosiasi dengan pihak eksternal (Silalahi, 2002:55).

Pemimpin ialah seseorang yang berpengaruh dan memiliki kekuatan untuk mengambil tanggung jawab terhadap semua anggotanya dalam setiap aktivitas organisasi untuk mencapai tujuan (Thoha, 1995:3). Kemudian, untuk lebih memahami mengenai seorang pemimpin, Siagian (1990:42) menyebut ada empat gaya kepemimpinan, yaitu : Otokratis; Militeristik; paternalistik; dan demokratis. Sedangkan menurut teori lain, ada juga tambah yaitu gaya kepemimpinan kharismatik, Gaya ini merupakan sebuah kewibawaan alamiah seorang pemimpin, diperoleh bukan karena adanya proses politik yang dilakukan secara sistematis. Memiliki ciri: (a) kewibawaan alamiah; (b) banyak pengikut; (c) Mempunyai semacam daya tarik yang metafisikal; (d) Terjadi ketidaksadaran dan irasional dari tindakan pengikutnya; (e) Tidak dibentuk oleh factor legalitas dan faktor latarbelakang, seperti aturan legal, formal, training atau Pendidikan; fisik tubuh, ekonomi, kesehatan, dan rupa (Athoillah, 2010:208).

Istilah kharismatik ini pertama kali diaplikasikan sebagai sifat kepemimpinan oleh Max Weber, seorang sosiolog Jerman. Menurutnya ada tiga bentuk otoritas dalam masyarakat yakni; tradisional, legal-rasional dan kharismatik. Bentuk Kharismatik itu sendiri digunakannya sebagai penjelasan 
A.Fachrudin, Herman, S. Anwar.

kepemimpinan berdasarkan pada persepsi kolektif masyarakat yang diberikan kepada seseorang (Allolangi, 2014:154)

Pengembangan adalah fungsi proses manajerial yang di dalamnya terdapat sebuah pelatihan yang berguna untuk sarana upgrading skill orang-orang yang terdapat dalam sebuah organisasi sebagai upaya dalam mempermudah sinkronisasi tugas pekerjaan dengan prospek karier setiap individu. Hal ini berdasarkan atas usaha supaya setiap anggota organisasi berkembang sehingga dalam bekerja itu berjalan secara efektif serta efesien (Munir, 2012:243).

Dakwah secara bahasa mempunyai pengertian sebagai mengajak, memanggil, seruan, dan permohonan, serta permintaan. Kemudian pada prakteknya, pada proses dakwah setidaknya wajib melibatkan tiga unsur utama, yakni : da’i, Materi, dan mad'u. Dakwah pun mengandung makna lebih luas lagi, yaitu sebagai kegiatan menyebarkan ajaran islam, amal ma'ruf dan nabi munkar, dan menyampaikan sebuah kabar yang gembira serta peringatan untuk seluruh manusia (Munir, 2012:17).

Menurut Munir (2012:245) dalam prosesnya, setidaknya pada proses pengembangan memiliki prinsip-prinsip tertentu yang menggiring kepada arah pengembangan dakwah, yaitu : (a) Identifikasi kebutuhan dalam sebuah pelatihan; (b) Memdorong optimisme serta percaya diri seorang da'i; (c) Membuat sebuah penjelasan berarti; (d) Membuat Panduan atau TOR pelatihan untuk mempermudah proses belajar saat pelatihan; (e) Memberi waktu dan kesempatan peserta untuk praktik secara feedback; (f) Melakukan evaluasi setelah pelatihan selesai; (g) Mendorong implementasi aplikatif dari keterampilan dan kemampuan yang diperoleh dalam proses kerja dakwah.

Pimpinan dakwah memiliki peran yang signfikan dalam pengembangan dakwah. Sikap dan ekspetasi mereka akan menciptakan suasana baik menumbuhkan profesionalisme, maupun melemahkannya. Oleh karena itu, diperlukan metode pengembangan dakwah, menurut Muhyidin (2002:137) ada beberapa metode dalam pengembangan dakwah, yaitu : (1) pengembangan sumber daya da'i; (2) pengembangan kualitas Mad'u; (3) pengembangan materi dakwah; (4) pengembangan media dan metode dakwah; (5) pengembangan sarana dakwah.

Istilah Pondok berasal dari Funduk yang berarti Hotel atau Asrama. Kemudian dalam buku Profil Pesantren menjelaskan bahwa pesantren berasal dari kata santri yang mendapat awalan pe dan akhiran -an artinya tempat tinggal para santri. Secara lebih luas lagi Mukti Ali menuturkan bahwa pondok pesantren merupakan 
sebuah lembaga pendidikan Islam yang memiliki sistem pendidikan dan pengajaran yang luas. Pondok Pesantren adalah lembaga pendidikan Islam, pendidikan Sosial, dan lembaga dakwah yang memiliki beberapa elemen yang saling melengkapi yaitu tempat pengajaran, peribadatan, Asrama, guru, dan murid, yang berada dalam suatu lingkungan tertentu yang dipimpin oleh seorang Kyai (Sudjoko, 1975:11). Secara singkatnya dalam elemen atau unsur yang ada dalam sebuah pondok pesantren, Soekamto (1999:45) menyebutkan ada lima unsur yaitu : (1) Masjid, (2) pondok, (3) kiai, (4) santri dan (5) kitab-kitab kajian klasik islami.

\section{HASIL DAN PEMBAHASAN}

\section{Sejarah Berdirinya YPI An-Annur Garut}

Cikal bakal berdirinya pondok pesantren YPI An-Nur Garut didirikan tahun 1870 oleh KH. Moehammad Jalaluddin dari Tuban Jawa Timur, dengan berbekal tekad untuk mengabdi demi perjuangan "Dinul Islam" dan kemerdekaan bangsa Indonesia, dengan dukungan keluarga/ kerabat dan masyarakat berupaya untuk menyelenggarakan lembaga pendidikan agama/ pesantren dengan pola pendidikan Pondok Pesantren Salafi (Tradisional). Masa kepemimpinan beliau di Pesantren tersebut hanya berjalan tidak lebih dari 10 (sepuluh) tahun, yakni tahun 1870 - 1880. Sepeninggal KH. Moehammad Jalaluddin muncullah beberapa orang penerus, yaitu: (1) K.H. Moeh. Anwar bin K.H. Moeh Djalaluddin, tahun 1880 -1891; (2) K. H. Nahrawi bin K. H. Moeh. Anwar, dari tahun 1891-1899; (3) K. H. Abdul Rahman bin K.H. Moeh. Anwar tahun 1899-1933. Pada periode pertama ini, fasilitas yang dimiliki oleh Pondok Pesantren "An-Nur" hanya 1 (satu) buah mesjid berukuran $8 \times 6 \mathrm{M}$, dan satu buah asrama santri yang kondisinya sangat darurat. Sedangkan sistem pendidikan yang digunakan pada masa itu adalah system tradisional (nonklasikal) dengan bidang kajian, antara lain: Al-qur'an dan Tafsir; Fiqih; Tauhid (aqidah); Bahasa Arab. Sepeninggal K.H. Abdul Rahman pada tahun 1933, kegiatan generasi ini disebut generasi pertama, setelahnya disebut generasi kedua karena sebelumnya Pondok Pesantren An-Nur sempat mengalami kevakuman., karena terjadinya keterputusan kader penerus. Sungguhpun demikian, kegiatan jemaah mesjid dan pengajian anak kampung (santri kalong) tetap berjalan. Generasi kedua Pondok Pesantren An-Nur ini diistilahkan "masa pembaruan", dipelopori oleh $\mathrm{KH}$ Ahmad Badruddin bin $\mathrm{KH}$. Abdul rahman pada tahun 1942 M. Beliau disebut pula "Pendiri Kedua" pondok 
A.Fachrudin, Herman, S. Anwar.

pesantren An-Nur, hal ini sebagai mana telah disampaikan karena pondok pesantren An-Nur sempat mengalami kevakuman dikarenakan terputusnya regenerasi karena pada saat KH. Abdurrahman wafat, putranya yakni K.H Ahmad Badruddin masih berusia dibawah 10 tahun, oleh sebab itu pesantren disebut mengalami kavakuman dikarenakan sempat tidak ada santri pendatang belajar di pesantren annur pada saat itu meskipun kegiatan belajar para santri kalong (santri masyarakat sekitar) tetap berjalan. bermodalkan ilmu, pengalaman dan wawasan yang dimiliki beliau serta kebulatan tekad guna melanjutkan perjuangan para pendahulunya disertai do'a restu dan dorongan ibundanya, beliau dengan tekun dan sabar, setahap demi setahap beliau menghidupkan dan membina kembali Pesantren Karanganyar. Pengembangan yang diusahakan oleh beliau ini meliputi dua bidang pengembangan, yaitu bidang pengembangan sistem pendidikan dan penertiban organisasi Pesantren.

\section{Pengembangan YPI Annur Garut}

Sepeninggal pimpinan pondok pesantren YPI An-nur, alm. K.H. Ahmad Badruddin, pada tahun 1999, kepemimpinan kelembagaan diamanatkan kepada K.H. Deden Muhammad Ilyas Badruddin, S,Pd.i., M.Si. Selaku penerus perjuangan ayahandanya, ia memiliki kewajiban untuk terus berjuang melanjutkan dan mengembangkan keberadaan pondok pesantren ini. Maka pada tahun 2001, diadakan penyegaran dan penataan keorganisasian serta menetapkan penyesuaian ad/ art yayasan pendidikan islam an-nur ini di bawah akta notaris heri hendriyana, s.h., nomor 20, tanggal 31 juli 2001, dan registrasi pengadilan negeri garut, nomor 35/yy/2000, tanggal 14 agustus 2000. Selanjutnya, sejalan dengan undang-undang nomor 14 tahun 2004 tentang yayasan. kemudian menetapkan susunan Pengurus Yayasan Pendidikan An-Nur sesuai dengan ketentuan, yang meliputi: (1) Dewan Pembina; (2) Dewan Pengurus; dan (3) Dewan Pengawas. Selain membenahi struktur dan keorganisasian pondok pesantren, beliau beserta jajaran kepengurusannya terus mengembangkan program kegiatan-kegiatan santri baik di pesantren maupun dalam kegiatan di sekolah. Susunan Pengurus YPI An-Nur Garut diantaranya adalah berikut ini : 1) Dewan Pembina diketuai oleh K.A Asep Saefudin; dan anggotanya adalah I.H.A Syarifuddin; Dr. Gagan M. Prawisarubarjah; Drs. Ii Syarifuddin; dan Abdul Malik, S.Ag, M.Si.; kemudian, 2) Dewan Pengurus diketuai oleh K.H. D. Muh. Ilyas Badruddin, S.Pd.I, M.Si.; Ketua Harian adalah Drs. Jafar Ismail M. K.; Sekretaris Umum H. AA Aman Abdurrahman, M.Pd.; Bendahara Uun, S.Ag.; Wakil Bendahara Iwa Abdul Wahid, 
S.Pd.; Ka Bidang Pesantren K. A. Jamaluddin; Ka Bidang Madrasah M. Musthafa S.T.A., S.Pd.I.; Ka Bidang Administrasi Iip Syarifuddin, S.Pd.; Ka Bidang Humas Drs. T.U. Effendi; Ka Bidang Hub Antar Lembaga Drs. Ahmad Sanusi, S.H., M.H.; Ka Bidang Usaha Deni Furqan Irawan; Anggota nya yaitu Para Kepala Madrasah/Lembaga Pendidikan, Majelis Madrasah, dan Ketua Komite Madrasah; Pembantu ialah K. Abdul Rosyid, S.Pd., S. Cahya, S.Ag., Iim Abd. Rohiom, S.Ag., Drs. U. Mukhtar, M.Si., Dedi Darmawan, S.H., dr. Hj. Elis, H. Aceng, H. Nanang, M. Cecep, Asep Suhendar, Aay Syarif Hidayat, S.Pd.I., Haris A. Sudarma, S.Pd.I.; (3) Dewan Pengawas diketuai oleh K. Moeh. Thaha; dan anggotanya ialah K. O. Sambas, Drs. R.S. Harisudin, Nur Shabur, S.Ag; Adapun Anggota Kehormatan PP YPI An-Nur diantaranya adalah Prof. Dr. H. Malik Pajar, K. H. Ilyas Ruhiat, Drs. H. Ahmad Syafi'i, M.Ba, M.Pd.; K. H. Cholil Ridwan, Lc., Drs. H. Ahmad Ma'sum, M.Sc., Drs. H. O. Rahmat Aziz, K. H. Satibi, K. H. Dudung Abdul Halim, MH., Ny. Hj. C. Marfuah, Prof. Dr. Jumhana, dan Drs. H. Slamet, BS, SH, MH. Pondok pesantren YPI An-Nur Garut berada di Komplek Pondok Pesantren YPI An-Nur Garut, Kp. Karanganyar RT06/RW 01 Desa Mekarmuya Kec. Malangbong Kab. Garut. Untuk menuju ke pondok pesantren tersebut sangat mudah bisa diakses angkutan umum (seperti bus, angkot, elf, dsb) maupun kendaraan pribadi karena lokasinya yang memang dipinggir jalan raya. Berada di tanjakan jalan raya jln raya malanbong-ciawi. Lokasi pondok pesantren YPI An-Nur cukup strategis dan memiliki iklim yang teduh karena banyak pepohonan, dan dikelilingi oleh sungai dan sawah sawah dari samping dan belakang. Dasar dan tujuan Pondok Pesantren YPI An-Nur Garut adalah ( Al-Qur'an: "Tidak sepatutnya bagi mukminin itu pergi semuanya (ke medan perang). Mengapa tidak pergi dari tiap-tiap golongan di antara mereka beberapa orang untuk memperdalam pengetabuan mereka tentang agama dan untuk memberi peringatan kepada kaumnya apabila mereka telah kembali kepadanya, supaya mereka itu dapat menjaga dirinya" Surat At-Taubah [9] ayat 122). Tujuan diselenggarakannya Pendidikan Pesantren An-Nur Garut adalah mendidik putera-puteri agar menjadi pribadi muslim yang punya rasa tanggung jawab sebagai abdi Allah SWT dan sebagai warga masyarakat dalam mencapai kebahagiaan dunia dan akhirat, dengan Taqwa mencapai ridha Allah SWT. Visi pondok pesantren YPI An-nur Garut: "Membentuk Pribadi Muslim yang Mutafaqih fid-din, mandiri, kreatif, serta cinta bangsa dan negaranya". Misi pondok pesantren YPI An-Nur Garut : Menyelenggaran pendidikan dengan memadukan sistem kurikulum kepesantrenan dan dan kurikulum pemerintah 
A.Fachrudin, Herman, S. Anwar.

serta menggiatkan pendidikan keterampilan, kepramukaan; Menggiatkan pembinaan tenaga kependidikan berdasarkan kompentensi keilmuan dan kebutuhan masyarakat; Menata, mengoptimalkan, dan mengembang sarana dan parasarana pendidikan; Membina kerja sama dengan masyarakat pendukung pendidikan. Strategi pondok pesantren YPI An-Nur Garut ialah dengan : melakukan pembinaan dan penguatan jaringan struktur organisasi baik secara intenal maupun eksternal; menyelenggarakan pembinaan dan peningkatan kerja sama dengan pemerintah dan masyarakat pendukung pendidikan; membina masyarakat melalui pendidikan agama yang mengakar kepada kepentingan umum dengan tanpa mempersoalkan perbedaan asal-usul atau latar belakang suku bangsa, politik serta aliran/ organisasi sosial keagamaan; dan Memberikan pelayanan/ pengembangan wawasan keilmuan melalui penyediaan sarana pembelajaran yang sesuai dengan perkembangan zaman, yang diharapkan mampu membuahkan generasi bangsa yang memiliki keseimbangan antara keimanan dan ketaqwaan dengan wawasan keilmuan dan kemampuan teknologinya; serta membina ekonomi umat sejalan dengan ajaran Islam. Moto Pondok Pesantren YPI An-Nur Garut “Berilmu Amaliah, Beramal Ilmiab”. Berdasarkan data Jumlah Madrasah dan Perguruan Tinggi di PP YPI An-Nur, memiliki : a) Raudhatul Athfal berjumlah 43 buah; b) TK/ TP Al-Qur'an berjumlah 34 buah; c) Madrasah Ibtidaiyah berjumlah 11 buah; d) Madrasah Tsanawiyah berjumlah 5 buah; e) Sekolah Menengah Pertama Islam Terpadu berjumlah 1 buah; f) Madrasah 'Aliyah berjumlah 1 buah; g) Sekolah Menengah Kejuruan An-Nur berjumlah 1 buah; dan Sekolah Tinggi Agama Islam berjumlah 1 buah. Selanjutnya, sarana dan prasarana Pondok pesantren YPI An-Nur diantaranya adalah : a) Masjid dan Mushola, Pondok pesantren YPI An-Nur memiliki sebuah masjid dengan dua lantai dengan luas 24 meter x 11 meter. Masjid ini salah satu tempat aktivitas santri dalam mengaji dan beribadah, pun masjid ini bisa digunakan tidak hanya untuk santri melainkan masyarakat sekitar dalam kegiatan ibadah, dan masjid bisa menampung sampai dengan 700 orang jamaah. Selain masjid, pondok pesantren YPI An-Nur juga memiliki sebuah mushola yang cukup luas bangunan dua lantai berlokasi di dekat Gedung sekolah MTs dan Gedung Asrama Putri Lebak. Mushola ini digunakan untuk ibadah, tempat mengaji, dan kegiatan tarbiayatul mubalighin sebagian santri putri pada malam minggu, dan digunakan juga oleh masyarakat sekitar. Jika hari hari biasa sekolah, mushola adalah tempat untuk sholat dzuhur dan Ashar siswi MTs dan Aliyah, sedangkan untuk siswa di Masjidnya; b) Asrama, Jumlah asrama di Pondok Pesantren YPI An-Nur Garut berjumlah 6 buah gedung 
asrama untuk menampung sekitar 1.230 orang santri. dan untuk asrama santriyah paling banyak Gedung asramanya. Diketahui untuk jumlah asrama putra yaitu hanya dua buah Asrama, untuk putra Gedung asrama I Berjumlah 6 ruangan kamar (Kobong) dan biasa dipakai untuk pengurus. Sedangkan gedung asrama II berjumlah 18 ruangan kobong Gedung ini diisi oleh seluruh santri putra. Setiap ruangan kobong putra diisi rata-rata antara 20-40 orang/ ruangan kamar dan didampingi oleh satu orang pembimbing kobong. Kemudian untuk asrama untuk putri seluruhnya berjumlah 700 an santri putri, terbagi menjadi 4 lokasi asrama putri, berdekatan dengan kediaman pengasuh supaya terkontrol dengan segala aktivitas santriyah. Secara keseluruhan ada 54 ruangan kobong putri, diisi rata-rata 10-15 orang per ruangan dengan di didampingi oleh satu orang pembimbing. Mekanisme penempatan santri baik untuk putra dan putri itu dikategorikan berdasarkan kelas atau angkatan, berbeda dengan dulu yang ditempatkan berdasarkan asal daerah asal, sehingga baik kelas tingkat MTs maupun Aliyah dicampur. Hal ini diperbaiki mengingat agar supaya para santri focus belajar dan lebih kondusif; c) Ruang Belajar, Untuk saat ini ruang belajar para santri pondok pesantren YPI An-Nur Garut biasa dilakukan masjid yang luas yaitu di serambi masjid disekat menjadi 5 ruangan dan mushola dekat asrama putri lebak yang bisa menampung sampai dengan seratus lebih santri putri. Adapun untuk pengurus khusus mengaji di rumah pimpinan pondok pesantren. Kadangkala diluar jadwal mengaji yang telah ditetapkan, para santri menggunakan kobong untuk sorogan kepada pengurus atau pembimbing dalam rangka menghapal kembali atau sekedar membaca ulang.; d) Kantor Pondok Pesantren, Pondok pesantren YPI An-Nur Garut memiliki sebuah ruangan kantor Sekretariat yang berlokasi di Gedung asrama II Putra lantai satu, berfungsi sebagai pusat kegiatan pengurus santri, juga tempat menerima tamu santri baik itu orang tua/ wali santri saat berkunjung. Penanggung jawab kantor asrama secara umum adalah pengurus asrama, secara teknisnya ada dua orang pengurus santri digilir jadwal piket untuk standby di kantor. Berbeda dengan pondok putri lebak, kantornya tidak digabung dengan kantor utama pondok putra. Karena untuk memudahkan proses administrasi dan kegiatan pengurus santri putri sendiri. Letaknya sendiri di lingkungan asrama pondok putri yang dibina oleh Kyai Bukhori dekat kantor dan sekolah MTs dan Mushola. e) Pengajar,Untuk tenaga pengajar atau ustadz di pondok pesantren YPI An-Nur Garut baik untuk mengajar santri putra ataupun santri putri berasal dari keluarga pondok pesantren sendiri yaitu yang pertama K.H Deden M Ilyas 
A.Fachrudin, Herman, S. Anwar.

Badrudin, M.Si, selaku Sesepuh pondok pesantren, Ust. H. Aa Aman Abdurrahman, M.Pd, Ust. H. Abdah M.Ilyas, S.Pd.I., Ust. Ejen, ust. Atep Hidayat, Ust. Aep Saepullah, Ust. Ii, Ust, Anha, dan Ust. Cecep arifin. Kemudian Ustadzahnya, yaitu Ustz. Hj. Ai Robiah, Ustz. Titin Julianti, Ustz. Siti Hajar, dan Ustz. Neng. Kemudian untuk pengajar santri putri di asrama lebak yaitu : K. Bukhori muslim, S.Pd.I, Ustz. Iyam Maryam Hamidah, Ustz. Dera Nurkhunisyah Darajat, Ust. Abdul Makky, Ust. M Bahar, Ustz. Iis nurhasanah, Ustz. Fajrin, Ust. Aaj A Muhajir, Ust. Zain A. Mudzakir, S.Pd.I., Ust. Drs. Ahmad Sanusi, S.H., M.H., dan Ust. Iwa A. Wahid, S.Pd. Adapun pengurus santri yang mengajar itu fungsinya hanya ngabadalan atau pengganti. Dan tentunya melalui ijin pimpinan pondok pesantren; f) Pelajaran, Proses Pembelajaran di Pondok Pesantren YPI An-Nur Garut memiliki tiga tingkatan yaitu ula, wusto, dan ulya. Untuk ula dan wusto itu santri tingkat pertama dan menengah biasa dibimbing oleh ustadz. Sedangkan untuk tingkatan ulya karena biasanya adalah santri yang cukup lama atau sudah menjadi pengurus itu langsung dipegang oleh pimpinan pondok pesantren YPI An-Nur Garut, dan tentunya tingkat ulya mendapat materi paling banyak dibanding dua tingkat sebelumnya; g) Lapangan Olahraga, Dalam rangka menyalurkan minat dan bakat santri terhadap olahraga juga untuk menjaga kondisi fisik santri tetap bugar, pondok pesantren YPI An-Nur Garut memiliki lapangan olahraga baik sepakbola, lapang volley dan basket. Lapangan volley dan basket berada di komplek Madrasah Aliyah, biasa digunakan oleh para santri baik ketika di sekolah ketika jadwal olahraga maupun ketika tidak ada jadwal mengaji di pondok. Lapangan ini juga biasanya digunakan untuk latihan drum band para santri, dan aktivitas luar lainnya; (h) Kantin, Pondok pesantren YPI An-Nur Garut memiliki kantin yang bertanggungjawab terhadap kebutuhan konsumsi seluruh santri. Kantin juga membuat jadwal jam makan dan menu makan berbeda setiap harinya. Dengan memperhatikan asupan gizi dan nutrisi dalam setiap masakannya guna untuk mendorong terjaga nya kesehatan seluruh santri pondok pesantren YPI An-Nur Garut. Walau pemikiran awalnya K.H. Ahmad Badruddin mendirikan madrasah (sekolah formal) guna memfasilitasi sanak keluarga dan warga masyarakat di sekitar Malangbong yang umumnya berekonomi lemah dan kesulitan membiayai pendidikan anak-anaknya ke kota-kota besar, namun dalam perkembangan selanjutnya pendidikan madrasah yang dipadukan dengan Pesantren menjadi pilihan alternative masyarakat muslim dengan berbagai tingkatan status sosial ekonominya, baik dari sosial sekitar wilayah Malangbong, maupun dari luar wilayah Malangbong, bahkan para santri/ siswa berdatangan 
dari luar wilayah Kabupaten Bandung. Saat ini santri/ siswa yang menimba ilmu di lingkungan Pondok Pesantren YPI An-Nur di samping dari sekitar wilayah Kabupaten Garut juga datang dari wilayah Kabupaten Tasikmalaya, Ciamis, Kota Banjar, Sumedang, Majalengka, Kuningan, Bandung, Cimahi, Purwakarta, Cianjur, Sukabumi, Bogor, Depok, Bekasi, Tanggerang dan Jakarta. Bahkan ada beberapa orang santri yang berasal dari pulau Sumatera. Alumni Pondok Pesantren YPI An-Nur sesuai dengan jenjang dan jenis pendidikan yang ditempuhnya tersebar mengisi berbagai sektor kehidupan. Umumnya para alumni banyak yang mengasuh lembaga pendidikan Islam. Selain itu banyak pula yang mencari kehidupan dan berprofesi sebagai buruh, pedagang, Pegawai Negeri Sipil/ TNI/ POLRI, Politisi, jasa dan sebagainya. Bahkan ada beberapa alumni yang kemudian menjadi tokoh (Ulama) dan pejabat di pemerintahan atau swasta. Para Alumni berkiprah melalui wadah Ikatan Keluarga Alumni (IKA) An-Nur yang mempunyai program pokok pengajian alumni mingguan, bulanan dan silaturrahim tahunan dengan berbagai kegiatan yang ikut mendukung kegiatan almamaternya.

\section{Biografi K.H Ahmad Badruddin}

Dilahirkan tahun 1918 di Karanganyar, Desa Mekarmulya, Kecamatan Malangbong, Kabupaten Garut. mempunyai sebutan nama kecil; Ujang. Ayahnya adalah K.H. Abdurrahman bin K.H. Muhammad Anwar bin K.H. Jalaluddin (Pendiri awal Pesantren Karanganyar). Ibunya adalah Ny. Raden Siti Rukiyah binti H. Raden Muhammad Ilyas (Eyang Bojong) binti Raden Surayuda (Wedana Malangbong). K.H. Ahmad Badruddin semasa hidupnya memiliki empat orang istri, Pertama kali beliau menikah dengan Ny. Eulis puteri K. H. Jalaluddin (Ajengan Pangkalan), kemudian menikah dengan istri kedua yaitu pada tahun 1942. Beliau menikah dengan Ny. Hj. Cicih Marfu'ah binti Muhammad Shobari Karanganyar. Dan istri ketiga ialah Ny. Siti Quraisyin binti K.H. Muhammad Nahrawi Karanganyar. Dan terakhir Isteri keempat adalah Ny. Euis binti K.H. Affandi Cibugel Cinagara Malangbong. Putera-putri beliau kurang lebih berjumlah 11 orang yaitu : 1) K. Asep Husen (alm), 2) Ny. Adah Sa'adah, 3) Ny. Ihat Prihatin, 4) Ny. Tati Fatimah Alm), 5) Ny. Didah, 6) K.H. Deden Muhammad Ilyas, S.Pd.i., M.Si. (Pengasuh Pondok Pesantren sepeninggal beliau), 7) Abdul Malik, S.Ag. 8) Ny. K.R. Habibah (dari isteri kedua). 9) Ny. Mamah (dari isteri ketiga), 9) Ny. Neneng, 10) Ny. Siti Rukiyah dan 11) Ny. Anjar (dari isteri 
keempat). Pendidikan Sewaktu kecil, beliau langsung mendapatkan pendidikan dari Ibu dan Ayah sampai belajar mengaji al-Qur'an dan sebagainya. Ayahanda meninggal tahun 1930. Walaupun pendidikan formal beliau sampai kelas III SR, namun beliau tetap terus belajar mengaji di bawah asuhan K.H. Muhammad Bukhori dan sebagainya. Berkat bimbingan dan dorongan ayahnya yang kedua (K. Moh. Yusya), beliau pernah belajar di Pesantren Ciomas Malangbong, Pesantren Ciherang Malangbong, Pesantren Tarogong Garut, Pesantren Cikelepu Balubur Limbangan, Pesantren Cangkuang Sumedang, dan Pesantren Jatipamor Majalengka. Karena materi pendidikan pesantren waktu itu belum menyentuh masalah-masalah mu'amalah (social-politik) akibat politik penjajah masa itu, sekitar tahun 1939 - 1940-an beliau tertarik dengan pendidikan modern yang didirikan oleh Alm. S.M. Kartosuwiryo yaitu Institut Suffab di Bojong Malangbong (waktu itu Alm. S.M. Kartosuwiryo sebagai Pimpinan Syarikat Islam di Garut). Selama beliau belajar di Institut Suffah, beliau aktif dalam kepanduan SIAP (Syarikat Islam Afdeling Pandu). Setelah itu, sekitar tahun 1940-an beliau terpilih menjadi Ketua Pemuda Muslim Indonsia (PMI). Salah satu program kegiatan organisasi tersebut adalah kursus bahasa asing bagi para pemuda dan para pemudi. Dalam kegiatan organisasi, beliau pada masa penjajahan bangsa Jepang dan awal kemerdekaan, aktif menjadi anggota Pengurus MIAI (Majelis Islam Ala Indonesia) Kecamatan Malangbong. Beliau aktif pula dalam barisan Hižbullah dan Sabilillah. Di awal masa kemerdekaan, beliau juga aktif sebagai anggota Pengurus Komite Nasional Indonesia (KNI). Beliau juga pernah menjadi Pengurus Koperasi Kecamatan Malangbong. Menjelang Pemilu pertama di Indonesia (1955) beliau aktif sebagai anggota Pengurus Partai Masyumi,dan yang paling beliau minati sejak tahun 1949/1950 adalah aktif dalam organisasi pendidikan. Sebagai Ketua PGII (Persatuan Guru Islam Indonesia) Anak Cabang Malangbong yang membina 30 Madrasah Diniyah se-Kecamatan Malangbong dan kursus Pembinaan Guru-guru Madrasah. Dalam pembinaan umat, sampai tahun 90 -an, beliau aktif sebagai Pengurus Majelis Ulama Indonesia (MUI) Kecamatan Malangbong. Pada tahun 60-an, beliau aktif sebagai Ketua Penasihat PII Cabang Malangbong. karena ada peraturan Pemerintah (Depag RI) bahwa madrasah yang resmi harus menginduk kepada salah satu organisasi atau Yayasan, maka melalui musyawarah dengan para Pengurus Pesantren, pemuka masyarakat dan wali murid, maka madrasah di lingkungan Pondok Pesantren Karanganyar bergabung ke organisasi PUI (MWB PUI dan PGA PUI). Selanjutnya beliau menjadi Ketua Pengurus PUI Cabang Malangbong. Sejak sekitar tahun 70-an, karena banyak reaksi yang tidak 
menguntungkan dan mengundang perpecahan, akibat kekurangfahaman beberapa pemuka agama setempat terhadap organisasi PUI, akhirnya beliau bermusyawarah dengan Dewan Pengurus Maka sejak itu PUI Cabang Malangbong dibekukan dan melepaskan atribut organisasi PUI atas seluruh madrasah di lingkungan PUI Cabang Malangbong. Kemudian beliau menjadikan seluruh asset pendidikan ini menjadi Lembaga Pendidikan Islam An-Nur (LPI An-Nur). Pada tahun 1980, atas keinginan beliau dan dorongan dari para pencinta pendidikan, guna meningkatkan pembinaan dan memayungi asset pendidikan di lingkungan LPI An-Nur ditingkatkan sebagai berbadan hukum dengan nama YAYASAN PENDIDIKAN ISLAM AN-NUR dengan Akta Notaris No. 56 Tanggal 22 Mei 1980 via Notaris Susana Zakariya, S.H., Bandung. KH. Ahmad Badruddin mengembangkan pesantren An-Nur sampai dengan wafat beliau tahun 1999 M. dengan upaya-upaya pembaruan/ inovasi pendidikan, dimana tidak hanya pola pesantren salafi tapi juga dikembangkan pula pendidikan modern/ sekolah. Sepeninggal Pimpinan Pondok Pesantren YPI An-Nur, Alm. K.H. Ahmad Badruddin, hari Rabu tanggal 18 Ramadhan 1419 Hijriyah bertepatan dengan tanggal 6 Januari tahun 1999 pukul 17.25 WIB. kepemimpinan kelembagaan diamanatkan kepada K. H. Deden Muhammad Ilyas Badruddin, S,Pd.I., M.Si, Selaku penerus perjuangan ayahandanya, ia memiliki kewajiban untuk terus berjuang melanjutkan dan mengembangkan keberadaan pondok pesantren AnNur Garut.

\section{Bentuk peran pimpinan pondok Pesantren YPI An-Nur Garut dalam penentuan Metode dan program dalam Pengembangan Dakwah}

Seorang pimpinan pondok pesantren senantiasa dianggap sebagi figur sentral yang diibaratkan kerajaan kecil yang mempunyai wewenang dan otoritas di lingkungan pesantren. Peran penting kyai terus signifikan hingga kini, kyai dianggap memiliki pengaruh sosial dan politik, karena memiliki ribuan santri yang taat dan patuh serta punya ikatan dengan lingkungan masyarakat sekitarnya. Kewibawaan, akhlak pimpinan dakwah menjadikan masyarakat dan khususnya para santri di pondok pesantren terkagum dan bersikap berhati-hati jika berhadapan dengan beliau. K.H Ahmad Badruddin berperan aktif dan penuh tanggung jawab dengan perhatiannya kepada setiap elemen di pesantren, dari hal yang kecil sampai yang besar. Amaliyah dan kreatifitas beliau yang istiqomah mampu memepengaruhi dan hasil membuat sikap yang baik dan keteladan bagi para santri dan masyarakat. 


\section{Bentuk Peran K.H Ahmad Badruddin}

Berdasarkan pada tiga teori menurut Mintzberg, bentuk peran KH. Ahmad Badruddin tergolong kepada semua bentuk tersebut hal ini karena beliau adalah seorang tokoh, pemimpin teladan, juga penghubung yang menggerakan pondok pesantren dan masyarakat sehingga menjadi berkembang. Dari semua bentuk peran, KH. Ahmad Badruddin menerapkan dan memiliki bentuk perannya pertama sebagai interpersonal. Kedua sebagai pemimpin yang informasional, dan yang ketiga sebagai desisional. Semua bentuk tersebut berada pada diri $\mathrm{KH}$ Ahmad Badruddin hal inipun menunjukan bahwa karishmatik seorang Kiai benarbenar ada dan terlihat dari jiwa kepemimpinan KH. Ahmad Badruddin.

Gaya kepemimpinan peran KH. Ahmad Badruddin tergolong pada tipe kharismatik. Karena kepemimpinannya bukan berdasarkan legalitas politik dan pembentukan yang dilakukan secara sistematis, kemudian karena adanya kewibawaan alami yang dimiliki, Tidak memaksakan kehendak namun memperhatikan kemampuan para santri. Kepemimpinan beliau berperan dengan memegang teguh norma-norma para pendahulu yang juga sebagai guru dan alim berpedoman kepada nilai-nilai spiritiul. Nilai-nilai ini menjadi dasar acuan dalam mengembangkan pondok pesantren. Sebagai tokoh dan pemimpin dalam perannya sebagai interpersonal, beliau memberikan contoh langsung dalam berprilaku tekun dan kesabaran kepada santri dan masyarakat, dan tidak segan untuk turun langsung mengerjakan aktifitas-aktifitas lainnya. Seperti ketika beliau membangun Pesantren ini. Sejak beliau mengajar di masjid yang telah reyot, dengan memakai alat tulis jarangking (gaplek) sebagai pengganti kapur tulis, sementara yang dijadikan papan tulisnya adalah pintu. Beberapa lama kemudian, untuk membuat papan tulis, beliau bersama saudaranya mengambil kayu dadap dari daerah Bakom Malangbong. Kayu tersebut diolah sendiri, sedang yang dijadikan catnya terbuat dari racikan arang, daun pepaya dan minyak tanah.

Dalam perannya sebagai informasional, beliau berdakwah dalam pengajian umum seminggu sekali termasuk dalam cara-cara ibadat pun yang dianggap perlu, terus menerus beliau berusaha luruskan. Misalnya shalat berjama'ah Rabu wekasan, shalat berjama'ah nisfu Sya'ban, shalat mu'adah setelah shalat Jum'at. Demikian juga mengenai kebiasaan shalat tarawih bulan Ramadhan, beliau menegaskan supaya jangan terlampau cepat, serta pada khutbah Jum'at beliau terjemahkan, menganjurkan untuk membiasakan shalat tahajud, adzan awal sebelum Shubuh. 
Pada masa tengah kehidupan masyarakat masih banyak hal-hal atau kebiasaankebiasan ritual animisme dan dinamisme yang dipandang menyalahi dan bertentangan dengan ajaran Islam, beliau merubahnya secara berangsur-angsur dan beliau hanya memberikan contoh-contoh dan penjelasan yang sangat bijaksana.

Dalam perannya sebagai desisional pun ketika beliau berunding pernah menolak beberapa tawaran oleh pihak luar. Misalnya, pada tahun 50-an, pernah beliau ditawari menjadi Kepala Inpeksi Pendidikan Agama Kabupaten Purwakarta, namun beliau tolak. Selain itu, ketika ke Majalengka, beliau ditawari sebidang tanah untuk menetap ke daerah tersebut dan segala fasilitas akan disediakan. Namun semua itu ia tolak, amanah sang ibunda yang menyuruh menunggui Masjid di Karanganyar. Dalam aspek ubudiyahnya, Keteguhan ini pun ia aplikasikan dalam aktivitas berorganisasi, ketika pimpinan rapat organisasi melalaikan shalat, beliau tidak segan-segan akan keluar dari organisasi. Kemudian pada masa revolusi dan masa transisi sosial politik pasca proklamasi kemerdekaan RI, sekalipun banyak alim ulama yang meninggalkan kampung (Pesantren) untuk ikut dalam gerakan Darul Islam di gunung, beliau tidak mau pergi meninggalkan Pesantren, sekalipun pernah dijemput oleh gurunya dari daerah Sumedang. Walaupun saat itu menjabat sebagai Kepala Penerangan DI untuk wilayah Malangbong Selatan. Disaat saat akhir hayatnya, bangunan terakhir beliau bangun dan beliau tinggalkan adalah Mushala An-Nur yang diperuntukan bagi kegiatan ibadah shalat para santri/pelajar MTs/MA serta warga sekitar.

\section{Metode pimpinan pondok pesantren dalam Pengembangan daya Da'i}

Dalam proses transfer ilmu dan peningkatan kemampuan dakwah para santri, Pimpinan pondok pesantren YPI An-Nur menggunakan tiga metode pengajaran yaitu metode ngagaeng/takror, metode bandongan, dan terakhir adalah metode tarbiyatul mubalighin untuk pengajaran kitab-kitab kuning dan latihan dakwah. Metode takror atau ngagaeng adalah termasuk metode yang khas di pesantren yaitu dengan ustadz membaca, menerangkan kitab secara perlahan berikut terjemahaannya. Kemudian para santri memperhatikan sambil mencatat terjemahaanya pada bawah baris huruf di dalam kitab yang dikaji, setelah selesai kemudian seluruh santri membaca Bersama dan mengulang terus menerus bacaan juga terjemahaan kitab tersebut. Diharapkan dengan dibaca berulang, para santri bisa hapal jika suatu saat ingin dibaca lagi. 
A.Fachrudin, Herman, S. Anwar.

Metode Bandongan atau sorogan adalah santri membaca kitab depan di bimbing oleh ustadz, apabila ada yang salah pada bacaan santri tersebut maka ustadz akan membetulkannya. Sistem metode sorogan ditempuh dengan cara guru menyampaikan pelajaran kepada santri secara individual biasanya di samping di kobong juga dilangsungkan di serambi mesjid, masjid atau terkadang di rumah pembina asrama. Di pesantren, sasaran metode ini adalah kelompok kecil dari santri baik satu kobong, atau satu kelompok kecil lainnya. Melalui sorogan, perkembangan intelektual santri dapat ditangkap secara utuh. Guru dapat memberikan tekanan pengajaran kepada santri-santri tertentu atas dasar observasi langsung terhadap tingkat kemampuan dasar dan kapasitas mereka. Sebaliknya, penerapan metode sorogan menuntut kesabaran dan keuletan pengajar, santri dituntut memiliki disiplin tinggi.

Dua metode tersebut digunakan oleh pimpinan pondok pesantren untuk mentrasferkan ilmu kepada para santri salah satunya sebagai bekal materi yang akan di dakwahkan oleh para santri melalui kegiatan Taribiyatul Mubalighin. Tarbiyatul mubtadiin adalah sebagai salah satu pengaplikasian dari apa yang dipelajari materi-materi yang didapat dari kegiatan kajian kitab-kitab. Secara umum kegiatan Tarbiyatul Mubalighin diselenggarakan di masing masing Lembaga di An-Nur baik di Pondok Pesantren yang utama, kemudian di sekolah. Metode ini diterapkan oleh pimpinan pondok pesantren An-Nur Garut kepada para santrinya sebagai wahana penerapan materi yang telah diberikan, dan juga sebagai ajang latihan dakwah para santri, agar terbiasa dalam berbicara di depan umum, membentuk mental santri, dan kemampuan pengembangan lainnya.

\section{Bentuk Pelaksanaan kegiatan dan evaluasi kegiatan pengembangan dakwah pondok pesantren YPI An-Nur Garut}

Dari beberapa program kegiatan, penulis memilih kegiatan Tarbiyatul Mubalighin sebagai salah satu kegiatan pengembangan dakwah yang akan dibahas lebih dalam, memuat bagaimana bentuk, proses pelaksanaan pengawasan serta evaluasi.

\section{Tarbiyatul Mubalighin}

Tarbiyatul Mubalighin adalah suatu program kegiatan yang wajib dilaksanakan dan diikuti oleh seluruh santri YPI An-nur Garut. kegiatan ini yang rutin dilakukan dan dikelola oleh pengurus santri bidang pendidikan di Pondok Pesantren YPI An-Nur Garut. Dalam kegiatan Tarbiyatul Mubalighin terdapat beberapa unsur 
penting yang mendukung berjalannya pelaksanaan kegiatan tersebut. Unsur inilah yang menjadi faktor berjalanya kegiatan Tarbiyatul Mubalighin ini.

Unsur-unsur yang ada dalam pelaksanaan kegiatan Tarbiyatul Mubalighin di Pondok Pesantren YPI An-Nur Garut yaitu dalam suatu kegiatan tidak terlepas dari orang-orang yang terlibat didalamnya, yaitu : a) Peserta, Santri merupakan peserta yang merupakan bagian dari sistem kaderisasi yang terlibat aktif, karena merekalah yang menjadi target kaderisasi untuk dilatih dan dibina manjadi kaderkader yang berkualitas di masa yang akan datang, karena merupakan sasaran utama yang dipersiapkan sebagai calon-calon mubaligh; b) Pengurus, yang dimaksud dalam hal ini adalah pengurus bidang pendidikan dalam mengelola kegiatan Tarbiyatul Mubalighin. Mereka tentunya bertanggungjawab penuh kepada pimpinan pondok pesantren jika terdapat pelanggaran dalam kegiatan Tarbiyatul Mubalighin sedang dilaksanakan. Pengurus santri bidang pendidikan memiliki tugas dalam hal menentukan jadwal, da’i dan petugas acara, menentukan tema, dan melakukan pengawasan dan evaluasi terhadap kegiatan; c) Pimpinan Pondok Pesantren, Dalam kegiatan Tarbiyatul Mubalighin, pimpinan pondok pesantren dalam terlibat dalam kegiatan ini, selalu diwakili oleh salah satu putranya yaitu $\mathrm{H}$. Aman Abdurrahman, M.Pd. selaku sekretaris umum dan Pembina Pondok Pesantren YPI An-Nur Garut.

\section{Bentuk dan Pelaksanaan Kegiatan dakwah}

Pada setiap kegiatan terdapat mekanisme-mekanisme yang harus dilakukan, Begitu juga kegiatan Tarbiyatul Mubalighin, memiliki beberapa mekanisme pelaksanaan, yaitu : 1) Perencanaan, dalam tahap perencanaan ini bagian pendidikan sebagai penanggung jawab kegiatan Pada setiap kegiatan terdapat mekanisme-mekanisme yang harus dilakukan : a) Membuat dan menentukan jadwal kelompok, Kelompok disini adalah berdasarkan kelas di sekolah antara kelas VII sampai dengan kelas XII, jadi bidang dakwah akan menentukan setiap minggu nya giliran kelompok berapa yang minggu depan akan tampil. Dipilih setiap kelas juga bertujuan untuk menumbuhkan kekompakan para santri dalam kegiatan Tarbiyatul Mubalighin; (b) Menentukan da'i dan petugas acara, Pengurus santri bertanggung jawab mempersiapkan siapa yang akan tampil pada minggu depan, tidak hanya da'i yang akan berdakwah tetapi petugas acara lain sebagai pelengkap kegiatan seperti MC, Qori, Khotib, pembaca sholawat, saritilawah, dan basthul kutub. Dan untuk santri yang mendapat giliran menjadi da'i maka 
A.Fachrudin, Herman, S. Anwar.

diwajibkan membuat bahan materi untuk didakwahkan baik dari kitab maupun materi dari sumber lainnya; (c) Menentukan tema dakwah mingguan, Tema dakwah untuk para da'i yang akan tampil itu berasal dari kajian setiap hari yang bersumber dari kitab-kitab kuning yang diajarkan di Pondok pesantren. Misalnya tema : adab terhadap guru, maka para peserta da'i harus membuat masing-masing materi dakwah dengan bahasa yang dipilih, baik bahasa arab, inggris, bahasa sunda, ataupun bahasa Indonesia; (d) Melakukan bimbingan kepada da'i, Bimbingan dilakukan khususnya kepada da'i yang akan tampil pada kegiatan Tarbiyatul Mubalighin, secara materi maupun persiapan teknis. Bimbingan ini dilakukan biasanya tiga hari sebelum pelaksanaan kegiatan; (e) Mempersiapkan tempat dan alat lainya, Untuk tempat kegiatan Tarbiyatul Mubalighin yaitu di masjid pondok pesantren YPI An-Nur, pengurus bidang pendidikan dan para petugas yang mendapat giliran mempersiapkan tempat agar bersih dan alat yang dibutuhkan; (2) Pelaksanaan, Pada tahap pelaksanaan, kegiatan Tarbiyatul Mubalighin diselenggarakan setiap satu minggu sekali, yaitu pada setiap hari minggu bada shalat subuh sekitar pukul 05 : 30 WIB - 07 : 30 WIB. Kemudian durasi ceramah setiap santri adalah 7-10 menit. Adapun tempat pelaksanaan adalah di masjid, dengan posisi seluruh santri putra di dalam masjid menghadap serambi depan yang diisi oleh seluruh santri putri. Dan tempat untuk para da'i dan petugas berada di tengah antara dalam masjid dan serambi depan sehingga bisa terlihat jelas oleh seluruh santri. Dalam kegiatan Tarbiyatul Mubalighin tentunya memiliki susunan acara, yaitu : Pembukaan, Pembacaan ayat suci Al-Qur'an, Saritilawah, Pembacaan sholawat, Demonstrasi Khutbah, Ceramah empat Bahasa, Babtsul Kutub, Pencerahan, Evaluasi, Penutup dan Do'a. Kegiatan Tarbiyatul Mubalighin merupakan kegiatan resmi dan wajib diikuti oleh seluruh santri. Maka dari itu setiap santri harus mengikuti dan mentaati ketentuan yang berlaku. Dalam setiap minggu ada empat orang da’i dari santri yang mendapat giliran tampil dan masing masing harus menggunakan Bahasa yang telah ditentukan. Dalam pelaksanaannya seluruh santri terlibat aktif, pengurus santri bidang Pendidikan bertanggung jawab penuh terhadap jalannya pelaksanaan kegiatan Tarbiyatul Mubalighin.

\section{Pengawasan dan evaluasi kegiatan pengembangan dakwah}

Untuk menghasilkan sesuatu yang diharapkan dalam sebuah kegiatan sehingga terus berkembang, maka diperlukan adanya pengawasan dan evaluasi sebagai bagian dari mekanisme kegiatan tersebut. Dalam hal ini pengawasan yaitu perhatian dan pengontrolan proses berlangsungnya kegiatan tersebut sehingga 
meminimalisir kesalahan dalam pelaksanaan, dan bisa segera diatasi melalui perbaikan dan peringatan yang sesuai dengan rencana yang dibuat. Dalam kegiatan Tarbiyatul Mubalighin pengawasan dan evaluasi dilakukan secara khusus oleh bagian pendidikan sebagai penanggung jawab dari kegiatan Tarbiyatul Mubalighin. pun pimpinan pondok pesantren melakukan pengawasan dan evaluasi secara tidak langsung.

Bentuk pengawasan yang dilakukan oleh pengurus santri bidang pendidikan terhadap pelaksanaan kegiatan Tarbiyatul Mubalighin : a) Melihat secara langsung jalanya kegiatan; b) Memberika teguran, peringatan dan sangsi.; c) pengarahan kepada da'i dan petugas lainnya; d) Menggerakkan dan memeriksa santri mengikuti kegiatan ini. Selain dilakukan pengawasan, juga dilakukan evaluasi, Kegiatan evaluasi dalam rangka untuk perbaikan dan penyempurnaan dan menumbuhkan motivasi bagi seluruh santri yang mengikuti kegiatan Tarbiyatul Mubalighin. Evaluasi ini dilakukan diakhir kegiatan oleh bidang pendidikan dari pengurus santri putra dan pengurus santri putri. Adapun bentuk evaluasi yang dilakukan adalah : a) Memberikan penilaian terhadap para petugas yang tampil dari kualitas isi materi dakwah yang menilai adalah dari bidang pendidkan dari putri dan putra; b) Memberikan hadiah penghargaan kepada kelas yang paling bagus pada acara puncak acara yaitu pada akhir tahun; c) Menyampaikan jadwal petugas untuk minggu. Selain evaluasi untuk para santri, kegiatan evaluasi juga dilakukan kepada seluruh pengurus pondok pesantren YPI An-Nur Garut yang diadakan rutin setiap dua kali setiap bulan, termasuk kegiatan tarbiyatul mubalighin pun dilaporkan perkembangannya saat evaluasi dengan pimpinan pondok pesantren.

\section{PENUTUP}

Berdasarkan hasil penelitian dan pembahasan yang berkaitan dengan judul skripsi Peran Pimpinan Pondok Pesantren Dalam Pengembangan Dakwah, maka penulis mengambil beberapa kesimpulan sebagai berikut : 1) Bentuk peran pimpinan pondok pesantren YPI An-Nur Garut berdasarkan teori Mintzberg, KH. Ahmad Badruddin tergolong kepada semua bentuk tersebut hal ini karena beliau adalah seorang tokoh, pemimpin teladan, juga penghubung yang menggerakan pondok pesantren dan masyarakat. Dalam penentuan metode peningkatan sumber daya da'i, menggunakan tiga metode yaitu metode ngagaeng/takror, metode bandongan, dan terakhir adalah metode tarbiyatul mubalighin. Kemudian penentuan program yang dikembangkan diantaranya adalah program pendidikan kepesantrenan, 
program pendidikan madrasah, program ekstrakulikuler di pesantren dan madrasah serta pembinaan dan pengembangan organisasi santri dan masyarakat; 2) Bentuk pelaksanaan dan evaluasi kegiatan pengembangan dakwah Tarbiyatul Mubaligbin adalah suatu program kegiatan yang wajib dilaksanakan dan diikuti oleh seluruh santri. Kegiatan ini rutin dilakukan dan dipertanggungjawabkan oleh pengurus bidang pendidikan di pondok pesantren YPI An-Nur Garut. Pada prakteknya para santri dituntut untuk belajar ceramah dengan pilihan empat bahasa, menjadi MC, batstul kutub, demonstrasi khutbah, seni hadroh, dan lain sebagainya. Bentuk dan pelaksanaan kegiatan Tarbiyatul Mubalighin memiliki beberapa mekanisme sendiri, diantaranya tahap perencanaan, tahap pelaksanaan, dan tahap pengawasan serta evaluasi. mekanisme ini dilakukan oleh bidang Pendidikan dan pengawasan dan evaluasi dalam kegiatan ini dilaksanakan sebelum dan sesudah kegiatan selesai.

Kemudian Saran dalam kegiatan Tarbiyatul Mubalighin. Penulis mempunyai sedikit masukan, yaitu : 1) perlunya perbaikan manajemen pelatihan dakwah seperti standar pengawasan dan evaluasi sehingga menjadi terukur dan efektif. dilakukan secara berkala dalam kegiatan tersebut oleh pimpinan pondok pesantren sehingga dalam prosesnya ada tindakan korektif sehingga kegiatan Tarbiyatul Mubalighin menjadi lebih baik lagi; 2) Dengan penuh kesadaran, skripsi yang telah disusun masih banyaknya terdapat kekurangan dan kelemahan, namun segala upaya yang telah dilakukan untuk menyempurnakan skripsi ini. Maka dari itu, penulis merekomendasikan bagi peneliti selanjutnya diupayakan skripsi ini menjadi salah satu acuan awal untuk meneliti lebih lanjut peran pimpinan pondok pesantren dalam pengembangan dakwah agar dapat lebih mendapat penyempurnaan dari hasil penelitian ini. 


\section{DAFTAR PUSTAKA}

Allolangi, Y. (2014). Kepemimpinan Transformasional sebagai Kepemimpinan Dakwah. Ilmu Dakwah: Academic Journal for Homiletic Studies, 6(1), 151-169. Athoillah, A. (2010). Dasar-Dasar Manajemen, Bandung: CV. Pustaka Setia. Ilaihi, W, \& Munir, M. (2006). Manajemen Dakwah, Jakarta: Kencana Prenada Media Group.

Muhyidin, A, Safei, A. A, Djalil, A. M. (2002). Metode Pengembangan Dakwah, Bandung: CV. Pustaka Setia.

Sadiah, D. (2015). Metodologi Penelitian Dakwah, Bandung: PT. Remaja Rosdakarya.

Siagian, S, P. (1995). Manajemen Stratejik, Jakarta: PT. Bumi Aksara.

Silalahi, U. (2002). Asas-asas Manaejemen, Bandung : Penerbit Mandar Maju.

Sukamto.(1999). Kepemimpinan Kiyai Dalam Pesantren. Jakarta: LP3ES.

Thoha, M. (1995). Kepemimpinan dalam Manajemen : sSuatu Pendekatan Prilaku, Jakarta : PT Raja Grafindo Persada.

Wahid, A. (1999). Pesantren Masa Depan, Bandung: Pustaka Hidayah. 
A.Fachrudin, Herman, S. Anwar. 